\title{
Prawne regulacje w zakresie taboru kolejowego Ocena bezpieczeństwa podsystemu „TABOR” $w$ zakresie wyceny $i$ oceny ryzyka
}

\begin{abstract}
Poniższy artykut jest ostatnim, piatym z cyklu pod wspólnym tytułem „Prawne regulacje w zakresie taboru kolejowego". Zawiera podstawowe informacje opracowane na podstawie różnego rodzaju dokumentów obowiqzujacych dla taboru kolejowego. Moga być one pomocne w pracy specjalistów zajmujacych się konstrukcja, badaniami oraz certyfikacja taboru kolejowego i jego głównych składników oraz $w$ pracy inżynierów zakładów produkujacych tabor, szczególnie $w$ zakresie oceny ryzyka dokonywanej przy wprowadzaniu istotnych zmian w eksploatowanym taborze. Artykut zawiera także tzw. linki do stron internetowych, na których dostepne sa cate teksty przytoczonych $i$ omawianych dokumentów.
\end{abstract}

\section{Wprowadzenie}

Zgodnie z wymaganiami wynikającymi z zapisu $\S 8$. ust. 2 [4] dokumentacja techniczna dołączana do deklaracji weryfikacji WE podsystemu obejmuje:

1) ...

7) raport $w$ sprawie oceny bezpieczeństwa wydany przez jednostke oceniajaca $w$ przypadkach określonych w rozporzadzeniu Komisji (WE) $n r$ 352/2009 z dnia 24 kwietnia 2009 r. w sprawie przyjęcia wspólnej metody oceny bezpieczeństwa $w$ zakresie wyceny $i$ oceny ryzyka, o której mowa $w$ art. 6 ust. 3 lit. a dyrektywy 2004/49/WE Parlamentu Europejskiego i Rady (Dz. Urz. UE L 108 z 29.04.2009, str. 4).

Przybliżenia wymagają dwa wyżej wymienione pojęcia: jednostka oceniająca i przypadki wymagające oceny ryzyka.

Zgodnie $\mathrm{z}$ art. 13 [1]:

14) ,jednostka oceniajqca” oznacza niezależna $i$ kompetentna wewnętrzna lub zewnętrzna osobę, organizacje lub podmiot, które przeprowadzaja badanie $w$ celu ocenienia, na podstawie dowodów, zdolności systemu do spetnienia wymogów bezpieczeństwa, które się do niego stosuja:

Status jednostki oceniającej, o której mówi wyżej wymienione rozporządzenie, można uzyskać na podstawie:

a) akredytacji przez krajową jednostkę akredytującą

b) uznania przez jednostkę uznająca.

Proces akredytacji lub uznania jest przeprowadzany $\mathrm{w}$ oparciu o określone kryteria.

Jednostka oceniająca musi uzyskać akredytację Polskiego Centrum Akredytacji, na zasadach określonych w wytycznych [6].

Jednostką oceniająca, w przypadku braku jednostek akredytowanych lub uznanych, może być krajowy organ ds. bezpieczeństwa (w Polsce jest Urząd Trans- portu Kolejowego), zgodnie z określonymi wymogami (art. 9 ust. 2 [1]). Określa to ust. 2 w art. 7 [1]:

2. Jeżeli państwo czlonkowskie uznaje krajowy organ ds. bezpieczeństwa jako jednostkę oceniajaca, spoczywa na nim obowiazek zapewnienia spetnienia przez ten krajowy organ ds. bezpieczeństwa wymogów określonych $w$ załaczniku II; $w$ takim przypadku funkcje jednostki oceniajacej petnione przez krajowy organ ds. bezpieczeństwa musza być wyraźnie niezależne od pozostałych funkcji krajowego organu ds. bezpieczeństwa.

Istotne zapisy o jednostkach zaangażowanych w proces oceny ryzyka muszą być przekazywane do Europejskiej Agencji Kolejowej zawiera ust. 1 art. 13 [1], mówiący o dostarczaniu informacji:

1. Tam gdzie ma to zastosowanie, ale nie później niż dnia 21 maja 2015 r., państwa członkowskie informuja Agencje o krajowej jednostce akredytujacej lub jednostce uznajacej, lub jednostkach uznajacych wyznaczonych na potrzeby niniejszego rozporzqdzenia, jak również o jednostkach oceniajacych, które uznaty zgodnie z art. 9 ust. 1 lit. a). Zgłaszaja one również wszelkie zmiany tej sytuacji $w$ terminie jednego miesiaca od chwili ich wystapienia. Agencja podaje te informacje do wiadomości publicznej.

Wymagania dla personelu jednostek oceniających, zależne od zakresu ocenianych zagadnień, przedstawia poniższa tablica.

Należy mieć na uwadze kilka wiążących zapisów dotyczących okoliczności, w których konieczne jest przeprowadzenie procesu oceny ryzyka. Zgodnie $\mathrm{z}$ art. 4 [1] wnioskodawca decyduje o znaczeniu zmian wprowadzonych w pojeździe, uwzględniając: 
Wymagania wobec personelu jednostki oceniającej ryzyko

Tabl. 1

\begin{tabular}{|c|c|c|c|c|c|}
\hline L.p. & $\begin{array}{l}\quad \text { Funkcja w procesie } \\
\text { inspekcji }\end{array}$ & $\begin{array}{c}\text { Personel } \\
\text { nadzorujący } \\
\text { umowy } \\
\text { lub zlecenia }\end{array}$ & Inspektorzy & Eksperci & $\begin{array}{l}\text { Kierownicy } \\
\text { techniczni }\end{array}$ \\
\hline 1 & $\begin{array}{l}\text { Ogólna wiedza z zakresu } \\
\text { zarzadzania ryzykiem }\end{array}$ & $x$ & $x$ & $x$ & $x$ \\
\hline 2 & $\begin{array}{l}\text { Wiedza z zakresu } \\
\text { obowiazzujacych przepisów } \\
\text { prawnych i norm (krajowych } \\
\text { i wspólnotowych) dotyczących } \\
\text { zarządzania ryzykiem }\end{array}$ & - & $x$ & $x+$ & $x$ \\
\hline 3 & $\begin{array}{l}\text { Wiedza i doświadczenie } \\
\text { w zakresie zarzadzania } \\
\text { ryzykiem, w tym wiedza } \\
\text { i doświadczenie w zakresie } \\
\text { standardowych technik analizy } \\
\text { bezpieczeństwa i odpowiednich } \\
\text { norm }\end{array}$ & - & $x$ & $x+$ & $x$ \\
\hline 4 & $\begin{array}{l}\text { Wiedza i doświadczenie } \\
\text { w ocenie elementów systemu } \\
\text { kolejowego, na które wpływa } \\
\text { zmiana }\end{array}$ & - & $x$ & $x+$ & $x$ \\
\hline 5 & $\begin{array}{l}\text { Wiedza dotycząca podsystemów } \\
\text { strukturalnych } \\
\text { (INFRASTRUKTURA, ENERGIA, } \\
\text { STEROWANIE, TABOR } \\
\text { KOLEJOWY) i obowiązujących } \\
\text { w tym zakresie TSI }\end{array}$ & - & $x$ & $x+$ & $x$ \\
\hline 6 & $\begin{array}{l}\text { Wiedza dotyczaca podsystemów } \\
\text { funkcjonalnych (UTRZYMANIE, } \\
\text { RUCH KOLEJOWY, APLIKACJE } \\
\text { TELEMATYCZNE) } \\
\text { i obowiązujących w tym zakresie } \\
\text { TSI }\end{array}$ & - & $x$ & $x+$ & $x$ \\
\hline
\end{tabular}

gdzie: X oznacza, że jednostka oceniajaca powinna zdefiniować kryteria i dogłębność wiedzy i umiejętności, a X+ oznacza konieczność pogłębionej wiedzy i umiejętności.

- skutki awarii

- innowacyjność

- złożoność zmiany

- możliwość monitorowania

- odwracalność zmiany

- skutek przeprowadzonych niedawno zmian.

Jeżeli proponowana zmiana nie ma wpływu na bezpieczeństwo, nie istnieje konieczność stosowania procesu zarządzania ryzykiem opisanego.

Zgodnie z [2] wnioskodawca do celów oceny swojej demonstracji zgodności wyznacza jednostkę notyfikowaną dla podsystemu „Tabor” lub jednostkę oceniająca.

\section{Wybrane wymagania dla różnych rodzajów taboru}

\subsection{Lokomotywy i tabor pasazerski}

Ocena bezpieczeństwa, w oparciu o ocenę ryzyka, dla lokomotyw i taboru pasażerskiego weryfikuje kompletność rejestru zagrożeń oraz poprawność analizy zagrożeń, doboru środków ograniczania ryzyka oraz przyjętych kryteriów akceptowalności ryzyka.

Specyfikacja TSI LOC\&PAS podaje dla 115 elementów pojazdów trakcyjnych i pasażerskich relacje pomiędzy wymaganiami zasadniczymi a wymaganiami szczegółowymi ujętymi w podrozdziałach rozdziału 4. tej specyfikacji. Zestawienie to wykorzystuje się dla zapewnienia kompletności rejestrów zagrożeń dla konkretnych pojazdów. Konieczne jest jednak ujęcie w rejestrze także innych zagrożeń właściwych dla danego typu pojazdu. Przykładowo wskazać można następujące kwestie wymagające szczegółowej analizy od identyfikacji zagrożeń poprzez wybór metody oceny do wyboru i weryfikacji spełnienia kryterium akceptacji ryzyka.

\section{Aspekty bezpieczeństwa}

Funkcje, które przyczyniają się do spełnienia zasadniczych wymagań w aspekcie „bezpieczeństwo” określono w tabeli w pkt 3.1 [4].

Wymagań bezpieczeństwa odnoszące się do tych funkcji ujęto w specyfikacjach technicznych określonych w odpowiedniej części pkt 4.2 (np. „bezpieczeństwo bierne”, „koła”).

Jeżeli dane specyfikacje techniczne muszą być uzupełnione wymaganiami wyrażonymi w postaci wymagań bezpieczeństwa, to zostały one również określone w odpowiedniej części pkt 4.2. 4).

Urządzenia elektroniczne i oprogramowanie stosowane w celu spełnienia funkcji kluczowych dla bezpieczeństwa opracowuje się i ocenia zgodnie z metodyką właściwą dla urządzeń elektronicznych i oprogramowania związanych z bezpieczeństwem.

W obszarze konstrukcji mechanicznej nadzorowi podlegają: interfejsy mechaniczne (sprzęgi wewnętrzne i końcowe oraz ratunkowe), dla których istotnym obszarem jest dostęp dla personelu.

\section{Dostep dla personelu do sprzegania / rozprzegania}

Pojazdy kolejowe powinny być skonstruowane tak, aby pracownicy nie byli narażeni na nadmierne ryzyko podczas sprzęgania i rozprzęgania lub akcji ratowniczych.

Aby spełnić to wymaganie, określone w pkt 4.2.2.2.3 pojazdy kolejowe wyposażone w układy sprzęgu ręcznego powinny spełniać następujące wymagania („przestrzeń berneńska”):

- Wymagane przestrzenie pokazane na rys. A2 w załączniku A powinny być wolne od części stałych. W związku z tym wymaganiem części składowe mechanizmu sprzęgającego znajdują się $\mathrm{w}$ położeniu bocznym względem jego linii środkowej.

W przestrzeni tej mogą znajdować się kable połączeniowe i węże elastyczne, jak również elastyczne odkształcalne elementy przejść. Pod zderzakami nie powinny znajdować się żadne urządzenia, które utrudniałyby dostęp do omawianej przestrzeni.

- Jeżeli zainstalowany został kombinowany sprzęg samoczynny i sprzęg śrubowy, dopuszczalne jest, aby głowica sprzęgu automatycznego ,wchodziła” $\mathrm{z}$ lewej strony w prostokąt berneński (jak widać na rys. A2), gdy jest on schowany i gdy używany jest sprzęg śrubowy.

- Pod każdym zderzakiem znajduje się poręcz. Poręcze wytrzymują siłę $1,5 \mathrm{kN}$.

\section{Przejścia mieddzywagonowe}

W przypadku, gdy zapewnione jest przejście międzywagonowe jako możliwość przemieszczania się pasażerów między jednym wagonem osobowym /pociagiem zespołowym a drugim, nie powinno to wiązać się $\mathrm{z}$ narażaniem pasażerów na nadmierne ryzyko. 
W przypadku, gdy przewiduje się eksploatację bez połączenia przejść międzywagonowych, powinna istnieć możliwość zablokowania pasażerom dostępu do tego przejścia.

Wymagania dotyczące drzwi w przejściach międzywagonowych w sytuacji, gdy dane przejście nie jest używane, wymieniono w pkt 4.2.5.8 „Kwestie dotyczące pasażerów - drzwi między pojazdami kolejowymi".

Wymagania dodatkowe przedstawiono w TSI „Dostępność dla osób o ograniczonej możliwości poruszania się” (pkt 4.2.2.7 „Przejścia”).

Wymagania te nie mają zastosowania $\mathrm{w}$ odniesieniu do końca pojazdów w przypadku, gdy omawiana przestrzeń nie jest przeznaczona do normalnego korzystania przez pasażerów.

\section{Hamowanie - wymagania bezpieczeństwa}

Dla uwzględnionych scenariuszy zagrożenia muszą być spełnione odpowiednie wymagania bezpieczeństwa określone w tabeli poniżej. Jeżeli w tabeli określono stopień ciężkości skutków, to należy wykazać, że odpowiednie ryzyko jest kontrolowane w zadowalający sposób, biorąc pod uwagę awarię funkcjonalna, która podstawowo wykazuje wiarygodne prawdopodobieństwo bezpośredniego spowodowania skutków o stopniu ciężkości określonym w tabeli.

Uklad hamulcowy — wymagania bezpieczeństwa

Tabl. 2

\begin{tabular}{|c|c|c|c|}
\hline & & \multicolumn{2}{|c|}{ Wymóg bezpieczeństwa, jaki ma byé spełniony } \\
\hline & $\begin{array}{c}\text { Awaria funkcjonalna i jej scenariusz } \\
\text { zagrozienia }\end{array}$ & $\begin{array}{c}\text { Powiązany } \\
\text { stopień cięzikościl } \\
\text { Konsekwencje, } \\
\text { którym należy } \\
\text { zapobiec }\end{array}$ & $\begin{array}{l}\text { Minimalna dozwolona liczba } \\
\text { kombinacji awarii }\end{array}$ \\
\hline \multicolumn{4}{|c|}{$\mathrm{Nr} 1$} \\
\hline & \multicolumn{3}{|c|}{$\begin{array}{l}\text { Dotyczy pojazdów kolejowych wyposażonych w kabinę maszynisty (kontrola ukladu } \\
\text { hamulcowego) }\end{array}$} \\
\hline & $\begin{array}{l}\text { Po uruchomieniu sygnału hamo-- } \\
\text { wania naglego brak opóźnienia } \\
\text { pociągu z powodu awarii w ukladzie } \\
\text { hamulcowym (całkowita i trwała } \\
\text { utrata sily hamowania). } \\
\text { Uwaga: należy uwzględnić urucho- } \\
\text { mienie przez maszynisté lub przez } \\
\text { system „Sterowanie”. Uruchomienie } \\
\text { przez pasażerów (alarm) nie ma } \\
\text { znaczenia dla niniejszego scena- } \\
\text { riusza. }\end{array}$ & $\begin{array}{l}\text { Ofiary śmier- } \\
\text { telne }\end{array}$ & $\begin{array}{l}2 \text { (nie dopuszcza się pojedyn- } \\
\text { czej awarii) }\end{array}$ \\
\hline
\end{tabular}

W badaniu dotyczącym bezpieczeństwa uwzględnia się dodatkowe układy hamulcowe na warunkach wymienionych w pkt 4.2.4.7 i 4.2.4.8.

Zgodność $\mathrm{z}$ wymaganiami podanymi w odniesieniu do zagrożeń nr 1 i nr $2 \mathrm{w}$ tabeli $6 \mathrm{w}$ pkt 4.2.4.2 należy wykazać za pomocą jednej $\mathrm{z}$ dwóch poniższych metod:

1. Zastosowanie zharmonizowanego kryterium określonego $\mathrm{w}$ dopuszczalnym poziomie zagrożenia rzędu $10^{-9}$ na godzinę.

Kryterium to jest zgodne $\mathrm{z}$ rozporządzeniem (WE) nr 352/2009 (zwanym dalej „CSM w zakresie wyceny i oceny ryzyka") załącznik I, pkt 2.5.4. c.d. tabl.2

Nr 2

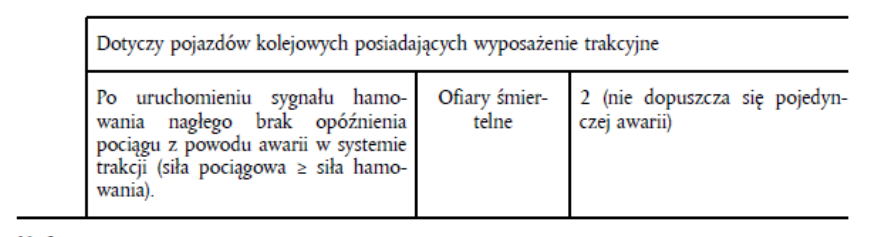

$\mathrm{Nr} 3$

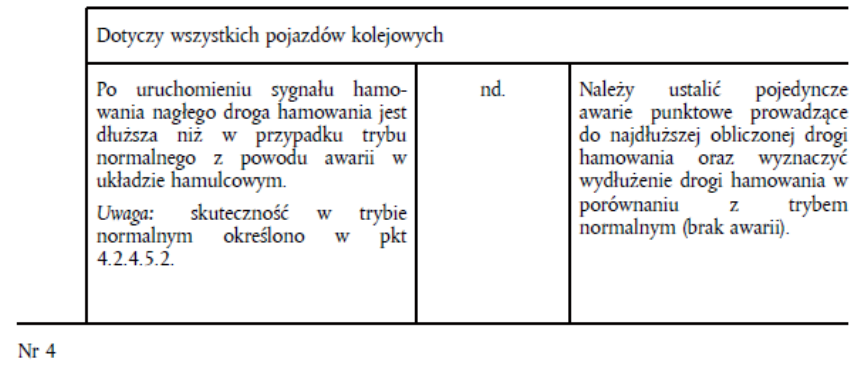

$\mathrm{Nr} 4$

\begin{tabular}{|l|l|l}
\hline \multicolumn{2}{|l}{ Dotyczy wszystkich pojazdów kolejowych } \\
\hline $\begin{array}{l}\text { Po uruchomieniu polecenia hamo- } \\
\text { wania postojowego brak sily hamo- } \\
\text { wania postojowego, brak urucho- } \\
\text { mienia sily hamowania (całkowita i } \\
\text { trwała utrata sily hamowania posto- } \\
\text { jowego). }\end{array}$ & $\begin{array}{l}2 \text { (nie dopuszcza się pojedyn- } \\
\text { czej awarii) }\end{array}$ & \\
\hline
\end{tabular}

Wnioskodawca powinien wykazać zgodność ze zharmonizowanym kryterium poprzez zastosowanie załącznika I-3 do CSM w zakresie wyceny i oceny ryzyka. Do celów wykazania zgodności zastosować można następujące zasady: podobieństwo do systemu referencyjnego (systemów referencyjnych), zastosowanie przyjętych sposobów postępowania, zastosowanie teorii prawdopodobieństwa.

Wnioskodawca powinien wyznaczyć jednostkę oceniająca, wspomagającą wykazanie zgodności, jakie on przedstawi: jednostkę notyfikowaną wybraną dla podsystemu „Tabor” lub jednostkę oceniająca, zgodnie z CSM w zakresie wyceny i oceny ryzyka.

Ocena powinna być udokumentowana w certyfikacie WE wydanym przez jednostkę notyfikowaną lub w deklaracji weryfikacji WE wydanej przez wnioskodawcę.

Deklaracja weryfikacji WE powinna zawierać stwierdzenie o zgodności z wymienionym kryterium i powinna być uznawana we wszystkich państwach członkowskich.

W przypadku dodatkowych zezwoleń na dopuszczenie do eksploatacji pojazdów stosuje się art. 23 ust. 1 dyrektywy 2008/57/WE lub

2. Zastosowanie wyceny ryzyka i oceny ryzyka zgodnie z CSM w zakresie wyceny i oceny ryzyka.

Deklaracja weryfikacji WE powinna zawierać informacje o zastosowaniu tej metody.

Deklaracja weryfikacji WE powinna zawierać informacje o zastosowaniu tej metody. 
Wnioskodawca powinien wyznaczyć jednostkę oceniająca, wspomagającą wykazanie zgodności, jakie on przedstawi, zgodnie z CSM w zakresie wyceny i oceny ryzyka.

Należy przedstawić raport $\mathrm{w}$ sprawie oceny bezpieczeństwa dokumentujący przeprowadzoną wycenę i ocenę ryzyka; raport ten powinien obejmować:

— analizę ryzyka,

- zasadę akceptacji ryzyka, kryterium akceptacji ryzyka oraz środki bezpieczeństwa, jakie mają być wdrożone,

- wykazanie zgodności z kryterium akceptacji ryzyka oraz ze środkami bezpieczeństwa, jakie mają być wdrożone.

Krajowy organ ds. bezpieczeństwa w zainteresowanym państwie członkowskim powinien uwzględnić raport $\mathrm{w}$ sprawie oceny bezpieczeństwa zgodnie z pkt 2.5.6 w załączniku I oraz art. 7 ust. 2 CSM w zakresie wyceny i oceny ryzyka.

W przypadku dodatkowych zezwoleń na dopuszczenie do eksploatacji pojazdów stosuje się art. 7 ust. 4 CSM w zakresie wyceny i oceny ryzyka w odniesieniu do uznania raportu $\mathrm{w}$ sprawie oceny bezpieczeństwa $\mathrm{w}$ innych państwach członkowskich.

\subsection{Wagony towarowe}

Zasady postępowania dla tego podsystemu są podobne jak dla lokomotyw i taboru pasażerskiego. Specyfikacja TSI WAG podaje dla 31 elementów wagonów towarowych relacje pomiędzy wymaganiami zasadniczymi a wymaganiami szczegółowymi ujętymi w podrozdziałach rozdziału 4. tej specyfikacji.

\section{Wymagania w zakresie bezpieczeństwa}

Konstrukcja układu hamulcowego jednostki musi zostać poddana ocenie ryzyka zgodnie z rozporządzeniem Komisji [1], biorąc pod uwagę ryzyko całkowitej utraty zdolności hamowania jednostki. Stopień ciężkości uznaje się za katastrofalny, kiedy:

- ma wpływ na samą jednostkę (kombinacja awarii), lub

- ma wpływ na zdolność hamowania więcej niż jednej jednostki (pojedyncza wada).

Spełnienie warunków C.9 i C.14 dodatku C uznaje się za spełnienie tego wymogu.

\section{Bezpieczeństwo przeciwpożarowe}

Należy zidentyfikować wszystkie istotne potencjalne źródła ognia (składniki wysokiego ryzyka) w danej jednostce. Celem aspektów bezpieczeństwa przeciwpożarowego projektu jednostki jest:

- zapobieganie powstawaniu pożaru,

- ograniczanie skutków ewentualnego pożaru.

Towary przewożone na jednostce nie stanowią jej części i nie muszą być uwzględniane przy ocenie zgodności.

\section{Przegrody}

Aby ograniczyć skutki pożaru, pomiędzy zidentyfikowanymi potencjalnymi źródłami ognia (składnikami wysokiego ryzyka) a przewożonym ładunkiem instaluje się przegrody ogniowe zachowujące szczelność ogniową przez co najmniej 15 Spposøb wykazania zgodności opisano w pkt 6.2.2.8.1.

\section{Materialy}

Wszystkie materiały trwałe zastosowane $\mathrm{w}$ jednostce mają ograniczone właściwości w zakresie zapalności i rozprzestrzeniania się ognia, chyba że:

- materiał jest oddzielony od wszelkich potencjalnych zagrożeń pożarowych $\mathrm{w}$ jednostce za pomoca przegrody ogniowej i jego bezpieczne stosowanie jest poparte oceną ryzyka, lub

— masa składnika $<400 \mathrm{~g}$ i składnik jest położony w odległości ? $40 \mathrm{~mm}$ w poziomie i ? $400 \mathrm{~mm} w$ pionie od innych niebadanych składników.

Sposób wykazania zgodności opisano w pkt 6.2.2.8.2.

\section{Podsumowanie}

Cykl artykułów zamieszczonych w kwartalniku Pojazdy Szynowe pod wspólnym tytułem „Prawne regulacje w zakresie taboru kolejowego", oprócz niniejszego obejmowała następujące tytuły:

- Unijne i krajowe przepisy dotyczące taboru kolejowego

- Akredytacja, autoryzacja i notyfikacja ośrodków certyfikujących i laboratoriów badawczych

- Ocena zgodności podsystemu „Tabor” i jego składników interoperacyjności

- Ocena zgodności podsystemu „Sterowanie urządzenia pokładowe" i jego składników interoperacyjności

Przedstawiły one istotne informacje w oparciu o aktualnie obwiązujące przepisy prawne. Pomocny w stosowaniu przepisów zawartych w TSI może być przewodnik wydany przez Europejską Agencję Kolejową [7].

Należy jednak mieć na uwadze duże tempo zmian przepisów dotyczących podsystemów kolejowych, co odnosi się nie tylko do Technicznych Specyfikacji Interoperacyjności będących podstawą oceny w zakresie ryzyka, lecz do wszystkich pozostałych opisanych wcześniej zagadnień.

W tablicy poniżej przedstawiono zestawienie kolejnych wersji TSI dotyczących bezpośrednio i pośrednio podsystemu tabor kolejowy, począwszy od $2008 \mathrm{r}$. Częstość zmian wskazuje na konieczność stałego śledzenia aktualności dokumentów regulujących obszar kolei europejskich. 


\begin{tabular}{|c|c|c|c|c|c|c|}
\hline Rok & TSI SRT & TSI PRM & HS TSI RST & $\begin{array}{l}\text { CR } \\
\text { LOC\&PAS }\end{array}$ & CR TSI WAG & TSI NOI \\
\hline 2008 & \multirow[b]{3}{*}{$\begin{array}{l}\text { Decision } \\
2008 / 163 \\
\text { (1st SRT TSI) } \\
\text { EiF: } 21 / 12 / 2007 \\
\text { DoA: } 1 / 7 / 2008\end{array}$} & \multirow{5}{*}{$\begin{array}{l}\text { Decision } \\
\text { 2008/164 } \\
\text { (1st PRM TSI) } \\
\text { EiF: } 27 / 12 / 2007 \\
\text { DoA: } 1 / 7 / 2008\end{array}$} & \multirow{5}{*}{$\begin{array}{l}\text { Decision } \\
\text { 2008/232 } \\
\text { (2nd HS RST } \\
\text { TSI) } \\
\text { EiF: } 21 / 2 / 2008 \\
\text { DoA: } 1 / 9 / 2008\end{array}$} & & \multirow{4}{*}{$\begin{array}{l}\text { Decision } \\
2006 / 861 \\
\text { (1st CR WAG } \\
\text { TSI) } \\
\text { DoA } \\
31 / 01 / 2008\end{array}$} & \multirow{3}{*}{$\begin{array}{l}\text { Decision } \\
\text { 2006/66 } \\
\text { Decision } \\
\text { 2006/860 } \\
\text { (2nd HS CCS } \\
\text { TSI) } \\
\text { DoA: } \\
\text { 7/11/2006 }\end{array}$} \\
\hline 2009 & & & & & & \\
\hline 2010 & & & & & & \\
\hline$\frac{2011}{2012}$ & & & & \multirow[b]{2}{*}{$\begin{array}{l}\text { Decision } \\
2011 / 291 \\
\text { (1st LOC\& } \\
\text { PAS TSI) } \\
\text { DoA: } 1 / 6 / 2011\end{array}$} & & \\
\hline 2014 & $\begin{array}{l}\text { Decision } \\
2011 / 291 \\
\text { (amendment) } \\
\text { DoA: } 1 / 6 / 2011\end{array}$ & & & & $\begin{array}{l}\text { Regulation } \\
321 / 2013 \\
\text { (2nd CR WAG } \\
\text { TSI) } \\
\text { EiF } 13 / 4 / 2013 \\
\text { DoA: } 1 / 1 / 2014 \\
\text { Regulation } \\
1236 / 2013 \\
\text { amendment } \\
\text { EiF 4/12/2013 } \\
\text { DoA: } 1 / 1 / 2014\end{array}$ & $\begin{array}{l}\text { Decision } \\
2011 / 229 \\
\text { (2nd NOI TSI ) } \\
\text { (CR only) }\end{array}$ \\
\hline 2015 & $\begin{array}{ll}\text { Regulation } & \\
1303 / 2014 & \text { (2nd } \\
\text { SRT } & \text { TSI) } \\
\text { EiF/DoA: } & \\
\text { 1/1/2015 } & \\
\end{array}$ & $\begin{array}{ll}\text { Regulation } & \\
1300 / 2014 & \text { (2nd } \\
\text { PRM } & \text { TSI) } \\
\text { EiF/DoA: } & \\
\text { 1/1/2015 } & \\
\end{array}$ & \multicolumn{2}{|c|}{$\begin{array}{l}\text { Regulation } 1302 / 2014 \\
\text { (1st merged RST TSI) } \\
\text { EiF/DoA: } 1 / 1 / 2015\end{array}$} & $\begin{array}{l}\text { Amendment on } \\
\text { CBB Positive } \\
\text { RISC opinion in } \\
\text { Nov } 2014\end{array}$ & $\begin{array}{ll}\text { Regulation } & \\
1304 / 2014 & \text { (3rd } \\
\text { NOI } & \text { TSI) } \\
\text { EiF/DoA: } & \\
\text { 1/1/2015 } & \\
\end{array}$ \\
\hline
\end{tabular}

DoA - date of application (data wdrożenia); EiF: entry in force (wejście w życie)

\section{Dokumenty odniesienia}

[1] Rozporzqdzenie Wykonawcze Komisji (UE) $n r$ 402/2013 z dnia 30 kwietnia 2013 r. w sprawie wspólnej metody oceny bezpieczeństwa w zakresie wyceny $i$ oceny ryzyka $i$ uchylajace rozporzqdzenie (WE) nr 352/2009

[2] Rozporzadzenie Komisji (UE) $n r$ 1302/2014 z dnia 18 listopada 2014 r. w sprawie technicznej specyfikacji interoperacyjności odnoszqcej się do podsystemu ,, Tabor - lokomotywy i tabor pasażerski" systemu kolei w Unii Europejskiej

[3] Rozporzadzenie Komisji (UE) NR 321/2013 z dnia 13 marca 2013 r. dotyczace technicznej specyfikacji interoperacyjności odnoszqcej się do podsystemu ,Tabor - wagony towarowe" systemu kolei w Unii Europejskiej $i$ uchylajace decyzje 2006/861/WE
[4] Rozporzadzenie Ministra Transportu, Budownictwa i Gospodarki Morskiej z dnia 6 listopada 2013 r. w sprawie interoperacyjności kolei (Dz. U. 2013 poz. 1297)

[5] Rozporzadzenie Ministra Infrastruktury i Rozwoju z dnia 15 grudnia 2014 zmieniajace rozporzadzenie $w$ sprawie interoperacyjności systemu kolei (Dz. U. 2014 poz. 1976).

[6] Akredytacja jednostek oceniajacych do dziatalności objętej Rozporzadzeniem Wykonawczym Komisji (UE) nr 402/2013. DAK-08. Wydanie 1. Warszawa, 13.03.2015 r.

[7] Przewodnik stosowania technicznych specyfikacji interoperacyjności (TSI). ERA/GUI/072011/INT. Wersja 1.02. 30.11.2012. 